\title{
Jigsaw untuk Membangun Karakteristik Pribadi Mahasiswa Bimbingan dan Konseling
}

\author{
Rian Rokhmad Hidayat \\ Program Studi Bimbingan dan Konseling, FKIP, Universitas Sebelas Maret \\ email: rianrh@staff.uns.ac.id
}

\begin{abstract}
Researchers at the initial observational data generation in Counseling education departemen students of LPTK A showed a low three aspects of their personal characteristics, namely empathy, unconditional positive regard, and congruence. Researchers interpret the lack of development of three aspects because todays lecture use the expository method that often pay less attention to the students organization of learning experiences, so that the material has been obtained simply forgotten. The use of jigsaw learning is expected to be a learning organization that is able to facilitate the student learning experience, so as to develop three aspects of these characteristics. This classroom action research took place in three cycles. Results obtained during the implementation of the study in the first cycle shows the average empathy, unconditional acceptance and genuines, still at the 'low' level. In the second cycle of the study note that the average of the three characteristics at the 'moderate' level. Whereas the third cycle study note that three characteristic aspects already reached the 'high'.
\end{abstract}

Keyword: jigsaw, personal character, counseling students

\begin{abstract}
Abstrak: Data pengamatan awal terhadap para mahasiswa prodi Bimbingan dan Konseling LPTK A menunjukkan tiga aspek karakteristik pribadi mahasiswa calon guru BK, yaitu empati, penerimaan tanpa syarat, dan ketulusan. Kurang berkembangnya tiga aspek tersebut patut diduga karena proses perkuliahan selama ini seringkali bersifat ekspositori yang kurang memperhatikan pengorganisasian pengalaman belajar, sehingga materi yang telah didapat terlupakan begitu saja. Penggunaan pembelajaran jigsaw diharapkan mampu menjadi pembelajaran yang mampu memfasilitasi pengorganisasian pengalaman belajar mahasiswa, sehingga mampu mengembangkan tiga aspek karakteristik tersebut. Penelitian tindakan kelas ini berlangsung dalam tiga siklus. Hasil yang diperoleh selama pelaksanaan penelitian pada siklus I menunjukkan rata-rata empati, penerimaan tanpa syarat dan kelutulusan, masih berada pada taraf 'rendah'. Pada penelitian siklus II diketahui bahwa rata-rata tiga karakteristik pada taraf 'sedang'. Sedangkan pada penelitian siklus III diketahui bahwa tiga aspek karakteristik telah mencapai taraf 'tinggi'.
\end{abstract}

Kata Kunci: jigsaw, karakteristik pribadi, mahasiswa bimbingan dan konseling

\section{PENDAHULUAN}

Pendidikan S1 Bimbingan dan Konseling (BK) diharapkan dapat menjadi wahana dalam membangun karakteristik pribadi mahasiswa calon guru BK dan sarana untuk menguasai khasanah teoritik BK bagi mahasiswa, sebagai syarat untuk menjadi konselor profesional. Oleh karena itu kurikulum pendidikan S1 BK hendaknya tidak hanya disusun untuk penguasaan teoritik dan keterampilan saja, namun juga diarahkan untuk membangun karakteristik pribadi calon konselor dalam diri mahasiswa. 
Dosen pengampu matakuliah menyampaikan materi yang menjadi tanggung jawabnya sesuai dengan silabus dan skenario pembelajaran yang telah disusun, namun kurang memperhatikan bagaimana cara pemeliharaan keilmuan tersebut baik dalam bidang kehidupan akademis maupun sosial mahasiswa. Mahasiswa pun juga menganggap ilmu yang didapat dari proses perkuliahan merupakan bahan persiapan untuk mendapatkan nilai yang tinggi saat ujian dan mengabaikan untuk diterapkan pada kehidupan sehari-hari. Pada hakikatnya, sebagai calon konselor para mahasiswa seharusnya mampu mengaplikasikan ilmu yang telah didapatkan dalam kehidupan sehari-hari sebagai bentuk latihan diri sebagai seorang konselor profesional. Mereka yang harus bekerja berdasarkan khasanah teoritik BK dan memiliki karakteristik pribadi yang baik sebagai seorang yang bergerak dalam bidang helping profession.

Beberapa data rendahnya karakteristik pribadi mahasiswa calon guru BK yang berhasil dihimpun antara lain: (1) terbentuk beberapa kelompok klik dalam kelas, (2) beberapa mahasiswa tampak dikucilkan dalam pergaulan, (3) memilih-milih teman saat membentuk kelompok belajar, (4) bepura-pura bersikap baik di depan teman yang kurang disukai ketika mengadakan interaksi, (4) mengerjakan tugas kelompok dengan cara membagi tugas sesuai dengan jumlah mahasiswa dan kemudian dikerjakan sendiri-sendiri, disatukan tanpa adanya diskusi sehingga masing-masing anggota bertanggung jawab atas materi yang dikerjakannya, (5) acuh terhadap teman yang menyampaikan pendapat atau presentasi, (6) menilai teman berdasarkan fisik semata, dan (7) sibuk bermain gawai saat dosen menjelaskan materi di depan kelas.

Beberapa gambaran data tentang rendahnya inferensi karakteristik pribadi mahasiswa calon guru BK di atas menunjukkan bahwa terdapat kekurangan dalam penerapan kurikulum yang telah disusun oleh lembaga. Akibatnya, mahasiswa semester 6 yang pada semester berikutnya akan melakukan PPL Bimbingan dan Konseling di sekolah, belum mampu menunjukkan karakteristik pribadi mahasiswa calon guru BK yang baik, bahkan dalam kehidupan sosial dengan teman di kelasnya. Kekurangan tersebut adalah terletak pada belum adanya penyertaan pemilihan strategi pembelajaran yang tepat, untuk membantu mahasiswa menghayati proses perkuliahan yang mendukung pengembangan karakteristik pribadi calon Guru Bimbingan dan Konseling untuk menghayati proses perkuliahan yang telah dijalaninya selama ini mulai dari semester pertama. Adanya penghayatan terhadap proses perkuliahan yang telah dijalani, seharusnya dapat terwujud dalam bentuk karakteristik pribadi calon guru Bimbingan dan Konseling yang baik.

Pengembangan pribadi konselor, tidak hanya harus disajikan dalam suatu matakuliah dengan beban sks tertentu, namun juga harus dijadikan sebagai tujuan afektif dari pembelajaran yang dilakukan kepada mahasiswa. Utamanya pada pembelajaran matakuliah yang berhubungan 
dengan profesi BK. Hal ini disebabkan oleh adanya desain pemberian wawasan pengetahuan dan pemberian kesempatan kepada mahasiswa untuk berlatih mengelola potensi personal dan profesionalnya dalam sajian pembelajaran matakuliah Profesi BK.

Disebutkan dalam deskripsi matakuliah Profesi BK, matakuliah ini dimaksudkan agar mahasiswa mampu mengkaji prinsip kerja profesi bimbingan dan konseling, melatih mahasiswa untuk mengenali, mengidentifikasi, dan sekaligus mengelola potensi personal maupun profesional. Di samping itu, mata kuliah ini juga menyiapkan mahasiswa agar dapat menyelenggarakan layanan bimbingan dan konseling sesuai dengan kewenangan serta kode etik profesional Guru Bimbingan dan Konseling. Nampak jelas bahwa dalam matakuliah ini, mahasiswa tidak hanya dituntut mengetahui apa saja aturan-aturan dalam profesi BK, namun juga dituntut untuk dapat mengembangkan karakteristik pribadi calon Guru Bimbingan dan Konseling dalam rangka menyelenggarakan layanan bimbingan dan konseling kepada konseli secara profesional.

Refleksi dilakukan bersama dosen pengampu matakuliah setelah dilakukan observasi pelaksanaan perkuliahan sebagai dasar perencanaan tindakan siklus I. Refleksi tersebut menghasilkan kesimpulan bahwa karakteristik pribadi calon Guru Bimbingan dan Konseling dikembangkan sebagai dampak pengiring pembelajaran walaupun tidak diajarkan dalam materi khusus. Salah satu cara pengembangan karakteristik pribadi calon Guru Bimbingan dan Konseling dapat dilakukan dengan proses menumbuhkan, melatih, dan membiasakan aspekaspek yang menjadi inferensi karakteristik pribadi Guru Bimbingan dan Konseling yang dilakukan pada setiap perkuliahan. Pembiasaan diskusi dan tanya jawab antar mahasiswa adalah bagian dari dinamika kelompok yang mampu meningkatkan kualitas hubungan antar mahasiswa dalam kelas. Pemilihan strategi pembelajaran yang tepat dapat membantu mahasiswa mengkonstruksi pemahaman dan mengorganisasikan pengalaman belajarnya.

Pribadi Guru Bimbingan dan Konseling adalah penentu keberhasilan layanan kepada konseli, sedangkan kemampuan akademik dan teknik keterampilan keilmuan adalah faktor eksternal yang mendukung. Ivey, Ivey, dan Zalaquett (2010) menyatakan bahwa Konselor harus mampu memadukan kekuatan-kekuatan pribadi sebagai internal skills dan keterampilanketerampilan yang dipelajari sebagai external skills. Dalam bukunya, digambarkan sebuah kerucut kemampuan konseling, yang mana kerucut tersebut menggambarkan keberadaan motif membantu dan mind skills yang melandasi kinerja Konselor. Keterampilan eksternal yang secara umum terdiri atas keterampilan memperhatikan, keterampilan mendengarkan, dan keterampilan mempengaruhi harus dikuasai agar Guru Bimbingan dan Konseling mampu menjadi kepercayaan konseli. 
Guru Bimbingan dan Konseling yang menguasai internal skills dan external skills dan mengaplikasikannya sebagai bagian pribadinya, diharapkan akan mampu membantu konseli secara tepat, sebab orientasi membantunya akan didasarkan pada internal frame of reference dari setiap konseli yang dibantunya. Senada dengan pendapat diatas, Rogers (1961) menegaskan bahwa Guru Bimbingan dan Konseling harus memiliki karakteristik pribadi yang baik untuk mendapatkan hasil konseling yang efektif, di antaranya pengertian berdasar empati (emphatic understanding), penerimaan tanpa syarat (unconditional positif regard), dan ketulusan (congruence).

Aspek pertama yaitu empati, Gladding (2009) menyatakan bahwa empati adalah kemampuan Guru Bimbingan dan Konseling untuk melihat, memahami, mengkonseptualisasi, dan mengkomunikasikan secara efektif kepada konseli mengenai perasaan, pilihan, dan pola pikir pada situasi atau sudut pandang konseli. Patterson (2005) menyebutkan bahwa empati memiliki tiga aspek atau tahapan dalam pelaksanaannya. Asumsikan bahwa klien mengijinkan konselor memasuki dunia pribadinya dan berusaha untuk mengkomunikasikan persepsi dan perasaan mereka pada konselor, konselor harus mau menerima pembicaraan mereka. Kedua konselor harus memahami komunikasi klien, untuk melakukannya konselor harus mampu menempatkan diri mereka pada tempat klien, untuk mengambil peran klien. Ketiga konselor harus mampu mengkomunikasikan pemahamannya pada klien.

Berdasarkan pengertian-pengertian tersebut di atas dapat ditarik kesimpulan bahwa empati adalah suatu kemampuan untuk menempatkan diri pada pikiran dan perasaan orang lain tanpa harus secara nyata terlibat dalam perasaan maupun tanggapan orang tersebut. Hal ini mencerminkan bahwa kondisi tersebut lebih nyata dirasakan sebagai situasi orang lain daripada situasi diri sendiri. Aspek Kedua yaitu penerimaan tanpa syarat, adalah penerimaan total terhadap pengalaman konseli tanpa syarat apapun, sebuah perhatian dan penerimaan yang tidak posesif (Gladding, 2009). Kesediaan konselor memiliki penghargaan tanpa menggunakan standar ukuran atau persyaratan tertentu terhadap individu sebagai manusia atau pribadi yang utuh (Mappiare, 1992). Carkhuff (1967) menyatakan bahwa penerimaan tanpa syarat menunjukkan konselor menerima kenyataan bahwa setiap konseli mempunyai hak untuk memilih sendiri, memiliki kebebasan, kemauan, dan mampu membuat keputusan sendiri.

Sebelumnya, Rogers (1961) menyatakan bahwa penerimaan tanpa syarat adalah sikap yang secara tidak langsung dari konselor dalam menghargai martabat dan nilai konseli sebagai manusia. Dari beberapa pengertian diatas, dapat disimpulkan bahwa penerimaan tanpa syarat adalah kesediaan konselor untuk menerima kenyataan bahwa setiap konseli mempunyai hak untuk memilih sendiri, kebebasan, kemauan, dan mampu membuat keputusannya sendiri. 
Aspek ketiga yaitu kelutusan, adalah konsistensi antara cara seseorang merasakan dan cara mereka mengungkapkan (Gladding, 2009). Ketulusan merujuk pada kemampuan konselor untuk menjadi asli, terbuka, dan membantu dengan sepenuh hati dan perasaan (Neukrug, 2003). Sebelumnya, Rogers (1961) menyatakan bahwa ketulusan merupakan kemampuan konselor meyatakan diri secara bebas dan mendalam tanpa pura-pura, tidak bermain peran, dan tidak mempertahankan diri. Dari beberapa pengertian diatas, dapat disimpulkan bahwa ketulusan menunjukkan konselor yang selalu menampakkan keseriusan dan keaslian pribadinya, sehingga tidak ada pertentangan antara apa yang diucapkannya dengan mimik wajah dan perilakunya.

\section{Penerapan Jigsaw untuk Pengembangan Karakteristik Pribadi Mahasiswa calon guru BK}

Proses pembelajaran yang banyak dipraktikkan sekarang ini sebagian besar berbentuk penyampaian secara tatap muka (lecturing), searah. Pada saat mengikuti kuliah atau mendengarkan ceramah, mahasiswa akan kesulitan untuk mengikuti atau menangkap makna esensi materi pembelajaran, sehingga kegiatannya sebatas membuat catatan yang kebenarannya diragukan (Depdiknas, 2008). Pola pembelajaran seperti di atas kurang memadai untuk mencapai tujuan pendidikan berbasis kompetensi. Diperlukan perubahan pola pembelajaran yang mampu meningkatkan kompetensi para peserta didik.

Perubahan dari content transmission paradigm menuju competency based instruction melibatkan penciptaan lingkungan dan pengalaman yang memungkinkan para mahasiswa mencari, menemukan, dan mengkonstruksi pengetahuan mereka sendiri. Pengajar diharapkan menjadi pembimbing dan mentor, membantu mahasiswa untuk mengakses, menginterpretasikan, mengorganisasikan, dan mentransfer pengetahuan untuk memecahkan masalah yang sesungguhnya, sementara itu mahasiswa memperoleh tambahan keahlian bukan hanya dari materi yang dipelajarinya melainkan juga pengalaman pembelajaran (Pedersen \& Liu, 2003).

Karakteristik pribadi konselor bukanlah suatu nilai yang bisa diajarkan kepada calon Guru Bimbingan dan Konseling melalui kegiatan perkuliahan biasa atau diajarkan dalam matakuliah khusus pengembangan pribadi calon Guru Bimbingan dan Konseling. Karakteristik pribadi konselor merupakan karakter yang bisa diperoleh dari aktivitas menumbuhkan, melatih, dan membiasakan sikap-sikap yang merupakan inferensi dari karakteristik pribadi konselor dalam kehidupan akademik dan sosial mahasiswa. Hal ini juga diperkuat pendapat Rosjidan (2002) yang menyatakan bahwa pengembangan program pendidikan BK tidak cukup memadai jika hanya menstandarisasi daftar mata kuliah yang diperlukan sarjana BK, tetapi juga harus menstandarisasikan pengorganisasian pengalaman belajar mahasiswa yang memungkinkan tercapainya pembentukan sikap pribadi dan kompetensi profesional BK. 
Seorang Guru Bimbingan dan Konseling harus menguasai teori, keterampilan konseling, dan karakteristik pribadi yang kuat. Ketiga hal tersebut tidak dapat diperoleh dalam waktu singkat. Utamanya karakteristik pribadi, diperlukan usaha pengembangan karakteristik pribadi calon Guru Bimbingan dan Konseling yang dilakukan secara terus-menerus selama menjalani pendidikan. Matakuliah Profesi BK sebagai matakuliah yang ditujukan untuk melatih sikap pribadi dan kompetensi profesional BK harusnya menjadi matakuliah yang tidak hanya mengajarkan pengetahuan mengenai profesi BK, tapi juga harus disertai pemeliharaan ilmu yang telah diberikan dalam kehidupan akademik dan sosial mahasiswa. Deskripsi matakuliah menunjukkan bahwa dalam matakuliah ini mahasiswa dilatih untuk mengenali, mengidentifikasi, dan sekaligus mengelola potensi personal maupun profesional disamping itu juga menyiapkan mahasiswa agar dapat menyelenggarakan layanan bimbingan dan konseling sesuai dengan kewenangan dan kode etik profesional Guru Bimbingan dan Konseling. Sehingga untuk mengembangkan karakteristik pribadinya, dosen perlu menyiapkan berbagai strategi pembelajaran yang efektif.

Penelitian tindakan ini berusaha untuk memperbaiki dan meningkatkan kualitas pembelajaran penyiapan calon Guru Bimbingan dan Konseling. hal ini senada dengan pendapat McNiff dan Whitehead (2006) mendefinisikan Penelitian Tindakan Kelas (PTK) sebagai bentuk penelitian yang memungkinkan pengajar melakukan investigasi dan evaluasi kinerjanya. Hal serupa juga disampaikan oleh Akbar (2009) yang menyatakan bahwa penelitian tindakan kelas berusaha meningkatkan kualitas dan hasil pembelajaran bersiklus.

Penerapan strategi pembelajaran jigsaw berguna bagi dosen untuk meningkatkan kualitas pembelajaran dan membantu mahasiswa untuk mengembangkan karakteristik pribadi Guru Bimbingan dan Konseling saat menempuh matakuliah Profesi BK. Tahapan-tahapan yang ada pada jigsaw, seperti diskusi dan tanya jawab merupakan bagian dari dinamika kelas, sehingga para mahasiswa yang ada di kelas mengalami proses kelompok untuk mencapai tujuan pengembangan karateristik pribadi Guru Bimbingan dan Konseling pada mahasiswa. Romlah (2006) menyatakan bahwa dinamika kelompok merupakan kegiatan-kegiatan yang dilakukan anggota kelompok, seperti diskusi, tanya jawab yang bertujuan untuk mengembangkan keterampilan hubungan antar anggota. Sedangkan proses kelompok mengacu pada tahap-tahap kegiatan yang berlangsung dalam kelompok yang membuat kumpulan individu-individu dalam kelas menjadi kelompok yang solid.

Tahapan awal pembelajaran jigsaw berupa pengaktifan skemata pengetahuan mahasiswa, dapat digunakan untuk mengigatkan mahasiswa bahwa materi yang dipelajari pada tiap pertemuannya hendaknya dihubungkan dengan karakteristik pribadi calon Guru Bimbingan dan Konseling yang menjadi salah satu dasar identitas profesional konselor. Menghubungkan 
setiap materi baru yang diajarkan dengan karakteristik pribadi calon Guru Bimbingan dan Konseling merupakan salah satu usaha untuk memelihara pengetahuan yang telah mereka miliki ke dalam kehidupan akademik dan sosial mereka, sehingga mahasiswa terlatih secara terusmenerus menghayati dan mengaplikasikan karakteristik pribadinya. Tahap pembagian kelompok yang dilakukan oleh dosen membuat mahasiswa tidak bisa memilih-milih kelompok berdasarkan teman yang disukainya saja, sehingga mereka mampu mengaplikasikan penerimaan tanpa syarat terhadap semua teman yang menjadi anggota kelompoknya.

Tahapan berikunya dari strategi pembelajaran jigsaw yang meliputi diskusi kelompok ahli dan presentasi terhadap kelompok asal. Proses diskusi yang terjadi dimaksudkan untuk menumbuhkan, melatih dan membiasakan karakteristik pribadi para mahasiswa. Empati dapat berkembang dari proses menerima pesan dari teman lain, memahami, merasakan perasaan, memaknai, menerima pesan, dan meresponnya dengan baik.penerimaan tanpa syarat muncul dari kemauan untuk terbuka terhadap ide, pikiran, gagasan, perasaan teman lain, dan dengan senang hati berbagi sumber kepada teman lain. Ketulusan dapat terwujud dari kegiatan mendukung kelebihan teman, mengekspresikan harapan, kejujuran, kepercayaan, dan tidak saling mengejek terhadap ide-ide yang disampaikan.

\section{METODE}

Pendekatan penelitian ini menggunakan pendekatan kualitatif. Adapun jenis penelitian kualitatif yang digunakan adalah penelitian tindakan kelas atau classroom action research. Penelitian tindakan kelas adalah penyelidikan sistematis yang dilakukan oleh guru peneliti, kepala sekolah, konselor sekolah, atau pengambil kebijakan lain dalam lingkungan belajar mengajar untuk mengumpulkan informasi tentang keterangan pelaksanaan sekolah, bagaimana mereka mengajar, dan seberapa baik siswa mereka belajar (Mills, 2007).

Subjek penelitian ini adalah mahasiswa Bimbingan dan Konseling, LPTK A yang sedang menempuh matakuliah Profesi Bimbingan dan Konseling. Kelas ini berjumlah 44 mahasiswa, yang terdiri dari mahasiswa 11 laki-laki dan 33 mahasiswa perempuan. Penelitian ini dilaksanakan dalam beberapa tahap, yaitu studi pendahuluan kemudian menyusun rencana tindakan. Kegiatan studi pendahuluan dilaksanakan untuk mengumpulkan data yang cukup sehingga dapat merumuskan kebutuhan. Langkah berikutnya yaitu menyusun rencana tindakan yang dilaksanakan dalam siklus tindakan. Tahap berikutnya yaitu pelaksanaan tindakan, pengamatan, dan refleksi hasil tindakan. Apabila permasalahan yang terkait dengan tujuan pengajaran maupun tujuan pendamping tidak tercapai, maka diadakan perbaikan pada siklus berikutnya. Pelaksanaan tindakan pada satu siklus mencakup empat tahap, yaitu perencanaan, pelaksanaan tindakan, observasi, dan refleksi. 


\section{HASIL}

\section{Temuan Penelitian Siklus I}

Penelitian siklus I yang dilakukan selama empat kali pertemuan pada akhirnya membawa peneliti untuk memperoleh beberapa temuan sebagai berikut. Pada penelitian siklus I, aktivitas dalam pembelajaran jigsaw telah berjalan dengan baik, namun kebiasaan perkuliahan yang berpusat dosen selama ini, yang membuat mahasiswa punya banyak kesempatan bermain acang masih terbawa, saat diskusi beberapa mahasiswa masih memegang acang. Jurnal Belajar Mahasiswa (JBM) atau format refleksi diri karakteristik pribadi calon Guru Bimbingan dan Konseling belum menggambarkan bagaimana mahasiswa menggunakan tiga aspek karakteristik pribadi saat diskusi belum terlaksana dengan baik. Pemberian penghargaan atas diskusi kelompok dan usaha mahasiswa dilaksanakan melalui penilaian hasil diskusi yang ditulis mahasiswa dalam kertas folio, sehingga mahasiswa sering merasa kurang dihargai usaha kerasnya dalam berdiskusi.

\section{Temuan Penelitian Siklus II}

Penelitian siklus II dilakukan selama tiga kali perkuliahan dengan pemerolehan temuan sebagai berikut. Tahapan strategi pembelajaran jigsaw, sebagaimana diamati oleh observer pendamping dan tertulis dalam Jurnal Belajar Mahasiswa (JBM), sudah terlaksana semua, namun efektifitasnya perlu ditingkatkan, agar lebih berdampak pada pengembangan tiga aspek karakteristik pribadi calon Guru Bimbingan dan Konseling. Mahasiswa lebih antusias dan bersemangat ketika diskusi kelompok ahli, sehingga waktu untuk aktif berdiskusi di kelompok asal seringkali kurang. Hal ini disiasati dengan memotivasi mahasiswa untuk melakukan diskusi kelompok ahli dengan cepat agar waktu untuk diskusi dikelompok asal lebih banyak dan lebih menarik lagi. Saat pembentukan kelompok, peneliti menggunakannya sebagai media untuk meminta mahasiswa menghayati dan mengembangkan karakteristik pribadinya. Sehingga, peneliti bisa memanfaatkan alokasi waktu yang singkat untuk pengembangan tiga aspek karakteristik sekaligus menjalankan tahapan jigsaw. Performansi mahasiswa mulai tertata pada siklus II. Keaktifan, empati, penerimaan, dan ketulusan lebih terarah. Jurnal Belajar Mahasiswa (JBM) dan format refleksi diri yang diisi oleh mahasiswa, menggambarkan bahwa indikator karakteristik pribadi konselor sudah banyak yang tercapai, tinggal memantapkan dan memeliharanya.

\section{Temuan Penelitian Siklus III}

Penelitian siklus III dilakukan selama tiga kali perkuliahan dengan pemerolehan temuan sebagai berikut. Tahapan strategi pembelajaran jigsaw sebagaimana diamati oleh observer pendamping dan tertulis dalam Jurnal Belajar Mahasiswa (JBM), sudah terlaksana semua. 
Adanya variasi penunjukkan ketua kelompok untuk mengatur jalannya diskusi kelompok bisa meningkatkan ketercapaian indikator pengembangan tiga aspek karakteristik pribadi calon Guru Bimbingan dan Konseling, karena konflik lebih terminimalisir. Performansi mahasiswa sudah lebih tertata, baik dari segi keaktifan, penerimaan anggota kelompok, empati, dan ketulusan saat melakukan diskusi kelompok dengan anggota yang ditentukan oleh dosen. Aktivitas belajar menggunakan jigsaw, yang mana mahasiswa terlibat dengan beberapa mahasiswa lain secara acak dan tidak terduga membuat mahasiswa mampu membiasakan karakteristik pribadi calon Guru Bimbingan dan Konseling dalam kehidupan akademik, tidak hanya secara teoritis saja.

\section{PEMBAHASAN}

Siklus I penelitian tindakan kelas dilakukan dengan tahapan yang diadaptasi dari Stephen Kemmis, yaitu perencanaan, pelaksanaan, pengamatan, dan refleksi. Siklus I penelitian dilaksanakan selama empat kali pertemuan. Sebagai peneliti dengan kedudukan outsiders in collaboration with insiders, perencanaan tindakan dilakukan peneliti bersama dengan dosen pengampu matakuliah Profesi BK. Perencanaan ini meliputi kegiatan pengumpulan data awal tiga aspek karakteristik pribadi mahasiswa calon guru BK, penyusunan skenario pembelajaran, dan penetapan indikator ketercapaian penelitian.

Pelaksanaan penelitian menggunakan strategi pembelajaran jigsaw Berangkat dari jurnal penelitian, observasi atas performansi peneliti yang dilakukan oleh observer pendamping dan jurnal belajar mahasiswa (JBM), diperoleh berbagai gambaran pelaksanaan tindakan. Tahapan jigsaw telah terlaksana semua, hanya saja efektivitasnya perlu ditingkatkan lagi. Beberapa faktor yang menyebabkan kekurangefektivan tersebut antara lain kurang efektifnya pemilihan strategi pemberian penghargaan terhadap kinerja mahasiswa. Pemberian penghargaan dilakukan dengan penilaian terhadap hasil kerja yang ditulis dalam folio bergaris, sehingga mahasiswa merasa kurang dihargai kinerjanya; dan kekurangsiapan mahasiswa mempelajari materi membuat waktu diskusi yang dibutuhkan lebih lama.

Alokasi waktu 100 menit untuk setiap pertemuan harus digunakan semaksimal mungkin untuk mengintegrasikan pembelajaran jigsaw dan juga pengembangan karakteristik pribadi mahasiswa. Pada siklus I, peneliti terlalu terpaku pada usaha membiasakan mahasiswa menggunakan karakteristik pribadi saat melakukan diskusi kelompok, dan kurang memotivasi dan menghargai usaha mahasiswa yang telah mencoba menjalankan strategi pembelajaran jigsaw ini, sehingga hasil yang didapatkan juga kurang maksimal. Padahal salah satu peran dosen dalam mengelola pembelajaran jigsaw adalah sebagai motivator, yang hal ini belum dilaksanakan secara maksimal. pengajar berperan sebagai fasilitator yang mengarahkan dan memotivasi siswa untuk belajar mandiri serta menumbuhkan rasa tanggung jawab serta siswa akan merasa senang mendiskusikan materi dengan kelompoknya (Hastomo, 2011). 
Refleksi penelitian dalam siklus I dilakukan peneliti melalui instrumen pengumpul data, pengamatan dari observer, jurnal rekaman penelitian dalam diskusi kelas. Melalui refleksi, diketahui bahwa tiga aspek karakteristik pribadi mahasiswa calon guru BK pada penelitian siklus I masih berada pada taraf pengembangan 'sangat rendah' dan 'rendah'. Tahapan jigsaw telah dilakukan secara keseluruhan untuk setiap satu kali pertemuan, dan kurangnya pemberian motivasi kepada mahasiswa untuk mencoba startegi pembelajaran baru ini masih dikesampingkan, menyebabkan proses pengembangan tiga aspek karakteristik pribadi mahasiswa calon guru BK terhambat. Akibatnya, indikator yang ditetapkan oleh peneliti pada perencanaan awal, masih sebagian kecil yang mampu dikuasai oleh mahasiswa.

Kelemahan temuan penelitian siklus I dijadikan bahan perencanaan kegiatan pada penelitian siklus II sesuai dengan kajian teoritis yang ada. Hal tersebut dapat diarahkan untuk memperbaiki kekurangan dan meningkatkan ketercapaian tiga aspek karakteristik pribadi mahasiswa calon guru BK yang diharapkan.

Pelaksanaan penelitian siklus II berlangsung selama tiga kali pertemuan. Penelitian siklus II ini dilaksanakan dengan harapan dapat memperbaiki apa yang belum terlaksana dan tercapai pada penelitian siklus I. Penelitian siklus II merupakan langkah yang ditempuh peneliti untuk meminimalisasi kekurangan yang ada pada penelitian siklus I, serta untuk meningkatkan ketercapaian indikator yang telah direncanakan sebelumnya.

Pada tahap perencanaan, peneliti berkolaborasi dengan dosen pengampu matakuliah Profesi BK untuk merencanakan tindakan. Adapun perencanaan yang ditetapkan adalah: (1) efisiensi strategi pembelajaran jigsaw dengan cara membagikan materi yang akan dibahas saat diskusi seminggu sebelumnya, sehingga mahasiswa memiliki kesempatan mempelajari di rumah sebelum berdiskusi, (2) memotivasi mahasiswa untuk melaksanakan jigsaw dengan semangat, (3) memantapkan tiga aspek karakteristik pribadi mahasiswa calon guru BK dengan sering mengingatkan mahasiswa untuk memelihara tiga aspek karakteristiknya saat berdiskusi dalam kelompok asal maupun kelompok ahli.

Berbeda dari penelitian siklus I yang dinilai masih kurang dalam mengintegrasikan pembelajaran dengan pengembangan tiga aspek karakteristik pribadi mahasiswa calon guru BK, peneliti dalam siklus II sudah berusaha untuk mengingatkan dan meminta mahasiswa menghayati tiga aspek karakteristik pribadi di setiap lini proses dan tahap pembelajaran. Tiga aspek karakteristik pribadi selalu dikaitkan dengan proses diskusi sebagai nurturant effect. Dengan demikian, saat mahasiswa berproses melakukan diskusi, selalu terselip usaha untuk memelihara tiga aspek karakteristik pribadi mahasiswa calon guru BK tersebut dalam proses pembelajarannya. Pada siklus II, mahasiswa mencapai pengembangan tiga aspek karakteritik 
pribadi 'sedang', namun taraf pengembangan ini dinilai masih belum sesuai dengan indikator ketercapaian yang direncanakan di awal penelitian.

Refleksi pada penelitian siklus II ini ditekankan pada aspek mengapa saat keseluruhan tahapan jigsaw terlaksana, namun indikator ketercapaian penelitian masih berada pada taraf 'sedang'. Faktor yang menyebabkan hal ini terletak pada kurang efektifnya proses pembelajaran dalam mengembangkan tiga aspek karakteristik pribadi mahasiswa calon guru BK. Dari refleksi ditemukan bahwa mahasiswa seringkali masih saling tunjuk untuk siapa yang akan melakukan presntasi pertama kali, hal ini ditengarai memunculkan konflik yang menghambat pengembangan karakteritik pribadi mahasiswa calon guru BK, khususnya pada aspek ketulusan.

Diperlukan usaha untuk mampu memunculkan tiga aspek karakteristik pribadi mahasiswa calon guru BK, salah satu yang direncanakan yaitu dengan memilih ketua kelompok untuk mengatur jalannya diskusi. Pemilihan ketua kelompok yang bertugas mengatur ini diyakini mampu untuk meminimalisir adanya konflik antar anggota yang mempermudah usaha pengembangan tiga aspek karakteristik pribadi mahasiswa calon guru BK, khususnya aspek ketulusan mahasiswa. Hal tersebut menjadi catatan pada penelitian siklus II yang memunculkan kesimpulan bahwa perlu untuk dilakukan penelitian siklus III untuk memperbaiki kekurangan yang ada, dan meningkatkan ketercapaian indikator penelitian.

Penelitian siklus III berlangsung sebanyak tiga kali pertemuan. Penelitian siklus II merupakan upaya perbaikan yang dilakukan oleh peneliti dari keterbatasan yang ditemukan pada penelitian siklus II. Perencanaan penelitian dilakukan peneliti bersama dengan dosen pengampu matakuliah Profesi BK. Perencanaan penelitian siklus III ini ditekankan pada strategi yang dipilih oleh peneliti untuk meningkatkan indikator pengembangan tiga aspek karakteristik pribadi mahasiswa calon guru BK. Hal ini disebabkan karena mahasiswa baru sampai pada taraf pengembangan karakteristik pribadi 'sedang', hingga akhir siklus penelitian II.

Dalam tahap perencanaan, peneliti dan dosen pengampu matakuliah Profesi BK memilih strategi menujuk ketua kelompok yang akan mengkoordinasikan jalannya diskusi di tiap kelompok, hal ini dikarenakan selama siklus I dan II seringkali mahasiswa saling menujuk temannya untuk memilih siapa yang akan presentasi terlebih dahulu. Pelaksanaan siklus III penelitian dilakukan peneliti dengan mengintegrasikan strategi yang telah direncanakan, yaitu penulisan jurnal dan pemilihan ketua kelompok ke dalam keseluruhan strategi jigsaw untuk pengembangan tiga aspek karakteristik pribadi mahasiswa calon guru BK.

Diskusi kelompok yang dipimpin ketua membuat proses pembelajaran lebih lancar dan mampu menciptakan lingkungan belajar yang aman dan interaktif, mahasiswa tidak perlu berebut siapa yang akan presentasi terakhir. Penciptaan lingkungan belajar yang aktif dan 
interaktif, membuat mahasiswa lebih banyak terlibat dalam kegiatan pembelajaran, sehingga mampu meningkatkan ketercapaian tujuan pembelajaran.

Pengamatan peneliti pada mahasiswa dan jurnal belajar mahasiswa (JBM) menemukan bahwa pemilihan ketua, penulisan jurnal, dan jigsaw sebagai strategi yang efektif dan tepat untuk mengembangkan tiga aspek karakteristik pribadi mahasiswa calon guru BK. Terlihat pula dari hasil analisis tiga aspek karakteristik pribadi yang dilakukan oleh peneliti, pada penelitian siklus III ini, mahasiswa mampu mencapai taraf perkembangan 'tinggi' untuk ketiga aspek kerakteristik pribadi. Hal ini menunjukkan bahwa semua indikator yang ditetapkan pada perencanaan awal penelitian dapat dicapai oleh mahasiswa. Namun, pada pengumpulan data performansi mahasiswa, tampaknya beberapa mahasiswa masih belum mampu secara keseluruhan memelihara karakteristik ini dalam kehidupan akademiknya. Hal ini terjadi karena proses pengembangan tiga aspek karakteristik pribadi mahasiswa calon guru BK membutuhkan waktu yang tidak sebentar dan harus dilakukan secara terus menerus, dan dipelihara sehingga tidak begitu saja bisa berwujud perilaku tampak yang bisa diobservasi langsung.

Refleksi yang dilakukan peneliti pada siklus III bersama dengan mahasiswa, menunjukkan bukti bahwa mahasisiwa senang menggunakan strategi pembelajaran jigsaw walapun memerlukan tenaga ekstra. Mahasiswa juga menilai bahwa karakteristik pribadi mahasiswa calon guru BK sangat diperlukan bagi mahasiswa agar mereka bisa menghadapi dan membantu berbagai tipe konseli dengan baik nantinya. Saat tiga aspek karakteristik pribadi mahasiswa telah baik konselor bisa menjadi lebih efektif dalam penyelenggaraan layanan bimbingan dan konseling. Ketercapaian yang ditangkap pada penelitian siklus III ini merupakan ketercapaian tertinggi oleh mahasiswa. Mahasiswa sudah mampu menghayati dan memlihara karakteristik pribadinya sendiri dalam kehidupan akademik maupun sosialnya.

Penelitian tindakan kelas dengan tujuan untuk mengembangkan tiga aspek karakteristik pribadi mahasiswa calon guru BK ini dilakukan sebanyak tiga siklus dengan berbagai temuan di setiap siklusnya. Temuan pada penelitian siklus I, direfleksi dan dijadikan bahan perbaikan bagi penelitian siklus II. Temuan penelitian siklus II direfleksi dan dijadikan bahan perbaikan siklus III. Temuan penelitian siklus III direfleksi dan mendapati hasil yang sesuai dengan tujuan awal penelitian. Temuan penelitian untuk setiap siklus diharapkan sesuai dengan harapan peneliti pada tahap perencanaan, namun adakalanya temuan penelitian tersebut menunjukkan sesuatu yang berbeda.

Temuan penelitian pada siklus I menunjukkan bahwa indikator yang ditetapkan oleh peneliti pada perencanaan awal penelitian, belum mampu dicapai oleh mahasiswa. Mahasiswa baru sampai pada taraf perkembangan 'rendah' untuk tiga aspek karakteristik pribadinya. Menilik ke belakang pada proses pelaksanaan strategi pembelajarannya pada siklus I penelitian 
memang belum sempurna, yang mana pemberian penghargaan kepada kinerja mahasiswa dilakukan melalui hasil kerja mahasiswa yang ditulis dalam kertas folio dan tidak disampaiakan secara langsung. Kekurangan lain yang bisa menjadi penghambat yaitu kurang diintegrasikannya karakteristik pribadi konselor pada saat mahasiswa melakukan diskusi. Hal ini mengakibatkan proses diskusi berlangsung tanpa disadari oleh mahasiswa bahwa dalam diskusi perlu memperhatikan tiga aspek karakteristik pribadi konselor yang dipakainya.

Temuan penelitian siklus II, menunjukkan bahwa mahasiswa memiliki perkembangan 'sedang' untuk tiga aspek karakteristik pribadinya, padahal yang diharapkan dalam indikator awal adalah, mahasiswa mampu mencapai taraf pengembangan 'tinggi'. Hal ini juga tidak lepas dari pelaksanaan pembelajaran jigsaw pada siklus II. Sesuai dengan instrumen pengumpul data, pengamatan, dan proses refleksi yang dilakukan, menjelaskan bahwa jigsaw dalam penelitian siklus II sudah dilaksanakan secara runtut dan menyeluruh. Masih kurangnya pengembangan tiga aspek karakteristik pribadi mahasiswa calon guru BK, kemungkinan besar berasal dari masih seringnya mahasiswa saling menunjuk siapa yang akan presentasi terlebih dahulu, dan berebut untuk presentasi paling akhir, sehingga pengembangan tiga aspek karakteristik pribadi yang 'tinggi' masih terhambat.

Temuan penelitian siklus III, menunjukkan bahwa mahasiswa berada pada taraf perkembangan 'tinggi', artinya bahwa indikator yang ditetapkan pada awal penelitian untuk tiga aspek karakteristik pribadi mahasiswa calon guru BK telah mampu dicapai. Hal ini merupakan peningkatan jika ditilik dari hasil penelitian di setiap siklusnya. Pada penelitian siklus III, peneliti dan dosen pembimbing melakukan perbaikan pada strategi yang digunakan untuk strategi jigsaw, yaitu dengan memilih ketua kelompok sehingga jalannya diskusi di kelompok bisa diatur oleh satu orang, yang hal ini bisa meminimalisir adanya konflik-konflik kecil dalam kelompok.

Diharapkan dengan kurangnya konflik yang berimplikasi pada pelaksanaan jigsaw secara efektif, dan pengembangan tiga aspek karakteristik pribadi akan meningkat. Hal ini sesuai dengan temuan penelitian terdahulu mengenai Jigsaw. Model Jigsaw memiliki dua dampak sekaligus pada diri mahasiswa, yakni dampak instruksional dan dampak pendamping, yaitu penguasaan konsep, saling ketergantungan positif, pemrosesan kelompok, kesadaran akan perbedaan, kepemimpinan kolektif, toleransi atas perbedaan, dan kepekaan sosial (Wibowo, 2010). Penggunaan strategi ini, dapat digunakan untuk memperbaiki proses dan hasil pembelajaran secara bersamaan. Sebagai perbaikan proses, peneliti memusatkan pembelajaran pada mahasiswa, sehingga hanya berperan sebagai fasilitator dan penegas saja, sehingga semua mahasiswa aktif dan terlibat dalam proses pembelajaran. Sedangkan sebagai perbaikan hasil, mahasiswa mampu meningkatkan prestasi belajarnya dan meningkatkan taraf pengembangan 
karakteristik pribadinya. Hal ini juga diperkuat hasil penelitian Wibowo (2010) yang menyatakan bahwa prestasi belajar mahasiswa dipengaruhi oleh strategi pembelajaran jigsaw.

Proses pengembangan karakteristik pribadi mahasiswa calon guru BK merujuk pada proses pengembangan karakter yang dikemukakan oleh Lickona (1991) "karakter tidak dapat diajarkan, akan tetapi diperoleh dari pengalaman, oleh karena itu harus dilatihkan dalam kehidupan sehari-hari”. Pada penelitian ini, proses pengembangan karakteristik pribadi mahasiswa calon guru BK dilakukan dengan tahapan memumbuhkan, melatih, dan membiasakan tiga aspek karakteristik pribadi mahasiswa calon guru BK selama proses perkuliahan berlangsung. Pada akhirnya mahasiswa mampu mengimplementasikan tiga aspek karakteristik pribadi konselor pada kehidupan akademiknya, yang berhubungan dengan pengembangan diri mahasiswa sebagai mahasiswa calon guru BK.

Implikasi temuan penelitian ini, perguruan tinggi sebagai salah satu lembaga pendidikan mempunyai tugas untuk membentuk tiga aspek karakteristik pribadi mahasiswa calon guru BK. Tiga aspek karakteristik pribadi ini merupakan proses dan hasil selama mahasiswa menempuh masa pembelajarannya di institusi pendidikan tersebut. Karakteristik pribadi bukanlah hal yang bisa diajarkan dalam matakuliah dalam satu semester saja, namun ini adalah proses yang harus disadari dan dilaksanakan oleh dosen dan mahasiswa selama menempuh pendidikan prajabatan konselor.

Selama ini, kebanyakan pembelajaran mahasiswa BK masih menggunakan metode konvensional, yaitu ekspositori dan penugasan oleh dosen pengampu matakuliah, sehingga proses penghayatan pengalaman belajar oleh mahasiswa seringkali terabaikan. Jika ada inovasi pembelajaran yang bertujuan untuk melibatkan peran aktif mahasiswa, hal ini masih sebatas pada aktivitas presentasi dan tanya jawab oleh dosen dan mahasiswa. Penelitian ini mengajak mahasiswa secara aktif berdiskusi dan berhubungan dengan individu lain di dalam kelas sebagai usaha pengembangan tiga aspek karakteristik pribadinya. Strategi pembelajaran ini diduga bisa menjadi strategi belajar yang menarik bagi mahasiswa dan lebih bermanfaat. Variasi strategi pembelajaran ini juga harus tetap mengacu pada tujuan pembelajaran dan tidak boleh lepas dari materi inti pembelajaran. Pembelajaran berpusat mahasiswa menempatkan dosen sebagai fasilitator dan motivator dalam proses pembelajaran. Sebagai fasilitator, dosen memegang kendali dalam proses pembelajaran. Dosen adalah sosok yang paling memahami karakteristik akademis dan sosial mahasiswa yang ada di kelas, sehingga pembentukan kelompok dalam pembelajaran jigsaw ini harus dilakukan oleh dosen, agar kelompok yang dihasilkan sesuai dengan karakteristik yang dipersyaratkan dalam jigsaw.

Sebagai fasilitator, dosen juga yang mengatur alokasi waktu, agar alokasi waktu untuk tiap pertemuannya bisa termanfaatkan dengan baik. Dengan kata lain, strategi ini 
mempersyaratkan persiapan diri bagi dosen, karena hasilnya akan berbeda dengan diskusi kelas yang dilakukan secara asal-asalan. Adanya persiapan dari dosen untuk membantu mempersiapkan mahasiswa mempelajari keilmuan secara lebih mandiri, akan sangat membantu ketercapaian tujuan pembelajaran serta peningkatan hasil pembelajaran dan pengalaman pada umumnya.

Penggunaan strategi pembelajaran jigsaw untuk pengembangan tiga aspek karakteristik pribadi mahasiswa calon guru BK berguna agar di lapangan nantinya mahasiswa tidak hanya bertindak berbasis penguasaan teoritis dan aplikasi tetapi juga mampu mengambil keputusankeputusan yang bersifat gawat darurat dan menyangkut kemaslahatan konseli secara mandiri dan bertanggung jawab.

Penelitian ini merupakan penelitian perbaikan pembelajaran, sehingga hasilnya tidak hanya dapat dimanfaatkan untuk perbaikan pembelajaran di jurusan bimbingan dan konseling saja, namun juga dapat digunakan sebagai ide perbaikan pembelajaran bagi helping profession yang lain. Penelitian ini dapat digunakan sebagai dasar untuk melakukan perbaikan pembelajaran persiapan para calon psikolog, pekerja sosial, perawat, dan dokter, yang membutuhkan karakteritik pribadi yang kuat dalam membantu kliennya. Penelitian ini juga bisa digunakan sebagai ide perbaikan pembelajaran pada penyiapan profesi guru pada umumnya. Profesi guru dapat dimasukkan karena seperti konselor, profesi guru juga merupakan helping profession, yang mana para guru juga menghadapi siswa dalam bekerja.

Strategi pembelajaran jigsaw ini juga memiliki beberapa kelemahan, diantaranya pelaksanaan strategi pembelajaran ini membutuhkan tenaga yang lebih banyak dari mahasiswa dibandingkan pembelajaran konvensional. Seringkali proses perpindahan tempat dari diskusi kelompok ahli ke kelompok asal membutuhkan waktu lama karena mahasiswa harus kembali ke tempat asalnya. Disini diperlukan usaha dosen dalam memotivasi mahasiswa agar bersemangat menjalankan proses pembelajaran.

Tiga aspek karakteristik pribadi mahasiswa calon guru BK merupakan karakteristik ideal bagi seorang konselor, mahasiswa masih mengalami kesulitan untuk mengadopsi nilainilai empati, penerimaan tanpa syarat, dan ketulusan apabila upaya pengembangan tiga nilai karakteristik tersebut tidak dilakukan secara berkesinambungan selama proses pendidikan mahasiswa calon guru BK.

\section{PENUTUP}

Penelitian tindakan kelas yang berlangsung tiga siklus dengan tujuan pengembangan tiga aspek karakteristik pribadi calon Guru Bimbingan dan Konseling ini, memiliki kesimpulan sebagai berikut. Dengan menggunakan strategi pembelajaran jigsaw, mahasiswa mulai diajak mengembangkan tiga aspek karakteristik pribadi calon Guru Bimbingan dan Konseling. 
Pengembangan tiga aspek karakteristik ini dilakukan secara terus menerus untuk mencapai indikator yang ditetapkan yaitu: (1) penerimaan tanpa syarat yang meliputi, menerima semua anggota kelompok; terbuka terhadap ide dan gagasan teman lain; berbagi sumber belajar dengan teman lain; (2) empati meliputi, mendengarkan pendapat teman; menempatkan diri dalam posisi pembicara; menerima, memaknai, dan menyampaikan pemahaman terhadap ide teman; (3) ketulusan meliputi, mengutarakan perasaan secara verbal; menerima kelebihan teman; kesesuaian antara ucapan dan respon non verbal.

Strategi pembelajaran jigsaw yang efektif untuk mengembangkan tiga aspek karakteristik pribadi calon Guru Bimbingan dan Konseling adalah yang dilakukan secara berkesinambungan dan terarah dengan baik. Keterarahan ini salah satunya bisa didapat dengan menunjuk salah seorang mahasiswa sebagai ketua kelompok yang memimpin diskusi untuk tiap kelompoknya. Menggunakan strategi tersebut, memungkinkan mahasiswa untuk terlibat aktif dalam keseluruhan proses pembelajaran, tanpa adanya konflik masalah urutan presentasi, sehingga memberikan pengalaman tersendiri bagi mereka.

Pemilihan strategi pembelajaran yang tepat dalam strategi pembelajaran jigsaw memiliki kontribusi positif untuk pengembangan tiga aspek karakteristik pribadi calon Guru Bimbingan dan Konseling. Pada akhir siklus III mahasiswa telah mampu mengembangkan tiga aspek karakteristik pribadi calon Guru Bimbingan dan Konseling pada taraf 'tinggi', walaupun beberapa mahasiswa masih kesulitan memelihara tiga aspek karakteristik pribadinya dalam kehidupan sehari-hari dengan teman di kelasnya. Hal ini dikarenakan usaha pengembangan tiga aspek karakteristik pribadi calon Guru Bimbingan dan Konseling tersebut tidak bisa hanya dilakukan dalam satu semester, tetapi harus berkesinambungan selama menempuh pendidikan prajabatan Guru Bimbingan dan Konseling.

Saran penelitian ini antara lain, dosen BK hendaknya menggunakan strategi pembelajaran jigsaw yang mendukung pengembangan karakteristik pribadi sebagai nurturant effect pada calon Guru Bimbingan dan Konseling; jurusan BK dalam mengembangkan kurikulum, khususnya matakuliah rumpun konseling menyertakan strategi pembelajaran jigsaw untuk mengembangkan tiga aspek karakteristik calon Guru Bimbingan dan Konseling; peneliti selanjutnya dapat mengujikan transferbility hasil penelitian pada kelas lain dengan karakteristik kelas yang sama untuk mengembangkan tiga aspek karakteristik pribadi calon Guru Bimbingan dan Konseling.

\section{DAFTAR PUSTAKA}

Akbar, S. (2009). Penelitian Tindakan Kelas: Filosofi, Metodologi, dan Implementasi. Yogyakarta: Cipta Media Aksara 
Carkhuff, R., Berenson, B. (1969). Beyond Counseling And Therapy. New York: Holt, Kenehart\&Winston

Depdiknas. (2008). Buku Panduan Pengembangan Kurikulum Berbasis Kompetensi Pendidikan Tinggi. Jakarta. Ditjen Dikti Depdiknas.

Gladding, S.T. (2009). Counseling: a Comprehensive Profession $\left(6^{\text {th }}\right.$ ed.). New Jersey: Pearson. Hastomo, A. (2011). Peningkatan Kualitas Perkuliahan BK di SD Program Studi S1 PGSD dengan Metode Kooperatif Learning Teknik Jigsaw. Retrieved from http://staff.uny.ac.id /sites/default/files/penelitian/Agung\%20Hastomo,\%20S.Pd.,\%20M.Pd/abstrak\%20lat\%20 fip2011\%20Jigsaw.pdf

Ivey, A. E., Ivey, M.B., \& Zalaquett, C.P. (2010). Intentional Interviewing and Counseling. Belmont: Brooks/Cole.

Lickona, T. (1991).Character Matters. New York: Bantam Books

Mappiare, A. (1992). Pengantar Konseling dan Psikoterapi. Jakarta: Raja Grafindo Persada McNiff, J., Whitehead, J. (2002). Action Research: Principles and Practice. London: Routledge Mills, G.E. (2007). Action Research: A Guide for the Teacher Researcher ( $3^{\text {th }}$ Ed.). New Jersey: Pearson.

Neukrug, E. (2003). The World of The Counselor: an Introduction to the Counseling Profession ( $2^{\text {nd }}$ ed.). California: Thomson Brooks/Cole.

Patterson, L.E \& Welfel, E.R. (2005).Counseling Process (6 ${ }^{\text {th }}$ ed.). California: Brooks/ Cole.

Pedersen, S. \& Liu, M. (2003). Teachers' Beliefs about Issues in the Implementation of a Student-Centered Learning Environment. ETR\&D, 51 (2); 57-76.

Rogers, C.R. (1961). On Becoming a Person. Boston: Houston-Mifflin.

Romlah, T. (2006). Teori dan Praktik Bimbingan Kelompok. Malang: UM Press

Rosjidan. (2002). Rekonseptualisasi Konsep BK dan Implikasinya pada Pola Pendidikan Konselor. Makalah disajikan pada Seminar dan Lokakarya Nasional Standardisasi Profesi BK, Jurusan PPB FIP UNY. Yogyakarta, 24-25 Oktober 2002.

Wibowo, L, A. (2010). Pengaruh Metode Cooperative Learning Teknik Jigsaw terhadap Prestasi Belajar Mahasiswa. Jurnal UPI. 6 (17), 